\title{
Pembingkaian Berita Politik di Media Online (Analisis Framing Pemberitaan Pidato Jokowi Pada Rapat Umum Relawan 4 Agustus 2018 di Mediaindonesia.Com, Tribunnews.Com dan Okezone.Com)
}

\author{
Erwin, Eko Harry Susanto \\ Erwin.915150114@stu.untar.ac.id
}

Fakultas Ilmu Komunikasi Universitas Tarumanagara

\begin{abstract}
This study discusses the framing analysis of the speeches made by Jokowi during the Volunteer General Meeting on August 4, 2018 at online media such as Mediaindonesia.com, Tribunnews.com, and Okezone.com. In the speech there was a saying "kalau diajak berantem juga berani" which eventually was controversial and gave rise to various pro and contra responses. By using Robert N. Entman's framing analysis, it can be seen how each media frames the news. Broadly speaking, Mediaindonesia.com defended and justified the speech and cornered the opposition as a source of problems in the speech controversy, Tribunnews.com seemed more inclined to defend the statement but not directly and more directed towards business interests, and Okezone.com defended and justifying the speech but there are still business elements in the news.
\end{abstract}

Keywords: Analysis Framing, Pidato Rapat Umum Relawan, Robert N. Entman

\begin{abstract}
Abstrak
Penelitian ini membahas mengenai analisis framing tentang pemberitaan pidato yang dilakukan oleh Jokowi saat Rapat Umum Relawan 4 Agustus 2018 pada media online Mediaindonesia.com, Tribunnews.com, dan Okezone.com. Dalam pidato tersebut terdapat ucapan "kalau diajak berantem juga berani" yang akhirnya kontroversial dan menimbulkan berbagai tanggapan pro dan kontra. Dengan menggunakan analisis framing Robert N. Entman dapat terlihat bagaimana masing-masing media membingkai pemberitaan tersebut. Secara garis besar, Mediaindonesia.com membela dan membenarkan pidato tersebut serta menyudutkan pihak oposisi sebagai sumber masalah dalam kontroversi pidato itu, Tribunnews.com terlihat lebih condong membela ucapan tersebut namun tidak secara langsung dan lebih mengarah pada kepentingan bisnis, dan Okezone.com membela dan membenarkan pidato tersebut namun masih terdapat unsur bisnis di dalam pemberitaannya.
\end{abstract}

Kata Kunci: Analisis Framing, Pidato Rapat Umum Relawan, Robert N. Entman

\section{Pendahuluan}

Tahun 2018 menjadi tahun politik karena pemilihan presiden (pilpres) diselenggarakan tahun 2019. Hal tersebut ditandai dengan banyaknya pemberitaan yang dilakukan oleh berbagai media yang sudah mulai membahas mengenai pasangan calon yang nantinya akan berlaga pada Pilpres 2019. Berita merupakan hasil akhir dari proses kompleks dengan menyortir dan menentukan peristiwa dan tema-tema tertentu dalam satu kategori tertentu (Eriyanto, 2011). Sedangkan dalam penyebarannya, dapat melalui berbagai cara dan salah satunya ialah melalui media online. Menurut Romli (2012), media online ialah media yang tersaji secara online di situs web (website) internet. Dengan pengertian tersebut maka dapat diartikan bahwa 
media online merupakan sebuah pemberitaan yang disebarkan secara online melalui situs website yang berada di internet. Dengan kelebihannya, media online dapat menyebarkan sebuah berita atau informasi hanya beberapa saat setelah kejadian tersebut terjadi.

Pada 4 Agustus 2018 lalu, media sempat dihebohkan dengan pemberitaan mengenai pidato yang dilakukan oleh Presiden RI Joko Widodo yang juga merupakan kandidat pada Pemilihan Presiden 2019. Dalam acara Rapat Umum Relawan Jokowi yang berlangsung di kawasan Sentul, Bogor. Seluruh wartawan diberi kesempatan meliput acara hingga lima menit pertama pidato dibacakan, setelah lima menit berlalu petugas istana dibantu dengan panitia meminta wartawan untuk meninggalkan ruangan tersebut. Namun masih ada beberapa wartawan yang tetap berada di dalam karena tidak terpantau oleh petugas istana maupun pihak panitia, sehingga beberapa wartawan tetap dapat meliput pidato Jokowi yang sempat menghebohkan tersebut dan tersiar ke publik. Pidato yang kontroversial tersebut dikarenakan terdapat ucapan Jokowi yang menyebut kalimat "berani diajak berantem" pada menit ke-8 detik ke-50. (http://jatim.tribunnews.com/2018/08/07/5fakta-di-balik-viral-video-pidato-jokowi-ajak-berantem-terbaru-responnya-tanggapiisu-provokasi?page=all\&_ga=2.76125397.1513799313.15350867561731761791.1527756552)

Akibat kalimat tersebut, pidato itu menuai berbagai kritikan, dari komentar yang pro terhadap pidato tersebut dan tidak sedikit pula yang kontra serta menganggap kalimat tersebut tidak pantas untuk disampaikan. Munculnya komentar pro dan kontra terjadi karena adanya perbedaan angle pemberitaan yang dilakukan oleh setiap media online. Hal tersebut terjadi karena saat ini merupakan tahun-tahun menjelang pemilihan presiden, sehingga dapat dikatakan tahun ini merupakan tahun yang penuh dengan politik.

Akibat pidato tersebut, tidak sedikit media online yang memberitakan pidato kontroversial itu hingga beberapa hari ke depan setelah pidato tersebut dibacakan. Oleh sebab itu, kehadiran media online diharapkan dapat bersikap netral serta tidak berpihak dalam setiap pemberitaannya, seperti sebagaimana fungsi utamanya yang sudah diatur dalam kode etik jurnalistik.

Dengan banyaknya media online, serta latar belakang dari masing-masing pemilik media tersebut bukanlah hal yang tidak mungkin ada perbedaan sudut pandang dari setiap pemberitaan yang dilakukan meskipun mengusung topik yang sama. Pemilihan sudut pandang, dapat mencerminkan ke arah mana media tersebut menuju dan arah itulah yang nantinya dapat menentukan bagaimana ideologi dari media tersebut.

Oleh sebab itu, saat ini seringkali terdapat berbagai perbedaan pada setiap masing-masing pemberitaan meskipun mengusung topik pembahasan yang sama, hal tersebut bisa saja disebabkan akibat pemilik media tersebut dan apa kepentingan dari pemilik media tersebut.

Saat ini, media-media online di Indonesia dimiliki oleh berbagai kalangan. Portal media berita online Okezone.com merupakan sebuah portal online yang dimiliki oleh PT Media Nusantara Citra (MNC) yang dimiliki oleh Hary Tanoesoedibjo yang juga merupakan Ketua Umum dari Partai Persatuan Indonesia (Perindo). MediaIndonesia.com merupakan salah satu unit usaha dari Media Group yang didirikan oleh Surya Paloh yang juga merupakan pemilik salah satu stasiun TV Metro TV. Selain itu Surya Paloh juga merupakan Ketua Umum dari Partai Nasional Demokrat (NasDem). Tribunnews.com merupakan salah satu dari anak 
perusahaan Kompas Gramedia, Kompas Gramedia merupakan sebuah perusahaan Indonesia yang bergerak di bidang media massa dan sekaligus pemilik dari Kompas.com dan Kompas TV.

Atas dasar pertimbangan dan landasan ini, penulis bertujuan untuk memahami, menganalisis dan membandingkan ketiga media tersebut, yaitu MediaIndonesia.com, Tribunnews.com, dan Okezone.com dalam bagaimana ketiga media tersebut melakukan pemberitaan pidato Jokowi pada Rapat Umum Relawan 4 Agustus 2018. Analisis ini dilakukan dengan tujuan untuk mengetahui bagaimana media-media tersebut dalam membingkai realitas dengan menggunakan metode analisis framing.

\section{Metode Penelitian}

Penelitian ini menggunakan pendekatan kualitatif dengan jenis penelitian deskriptif. Metode yang digunakan dalam penelitian ini ialah analisis framing yang dikemukakan oleh Robert N. Entman. Peneliti ingin menganalisis berita mengenai pidato yang dilakukan oleh Jokowi pada Rapat Umum Relawan 4 Agustus 2018 pada media online Mediaindonesia.com, Tribunnews.com, dan Okezone.com.

Pengumpulan data dalam penelitian ini dilakukan dengan studi pustaka, wawancara, dan penelurusan data online. Subyek dalam penelitian ini ialah portal berita media online Mediaindonesia.com, Tribunnews.com dan Okezone.com, sedangkan objyeknya ialah artikel berita mengenai pidato Jokowi pada Rapat Umum Relawan 4 Agustus 2018 yang disampaikan Mediaindonesia.com, Tribunnews.com, dan Okezone.com.

Teknik analisis data yang digunakan dalam penelitian ini ialah model analisis data kualitatif Miles dan Huberman, terdiri atas (1) reduksi data sebagai proses pemilihan, (2) penyajian data, (3) menarik kesimpulan/verifikasi (Susanto, 2018: 69). Pada keabsahan data peneliti menggunakan triangulasi sumber sebagai teknik keabsahan data pada penelitian ini.

\section{Hasil Penelitian}

Tabel 1. Hasil Temuan Pada Mediaindonesia.com

\begin{tabular}{|c|c|c|}
\hline No & Judul Berita & Temuan \\
\hline 1. & Golkar Anggap Ucapan Jokowi Soal "Berantem" & Golkar membela \\
\hline 2. & $\begin{array}{l}\text { Mendagri: Tak Ada Ajakan Kekerasan dalam } \\
\text { Pidato Jokowi }(06 / 08 / 2018)\end{array}$ & $\begin{array}{l}\text { Mendagri membela ucapan } \\
\text { Jokowi }\end{array}$ \\
\hline 3. & $\begin{array}{l}\text { Presiden Minta Pidatonya Dipahami Secara Utuh } \\
(07 / 08 / 2018)\end{array}$ & $\begin{array}{l}\text { Jokowi meminta pidatonya } \\
\text { tidak dipotong }\end{array}$ \\
\hline 4. & $\begin{array}{l}\text { Tidak Ada Amarah, Pidato Jokowi Justru Anjurkan } \\
\text { Persatuan }(07 / 08 / 2018)\end{array}$ & $\begin{array}{l}\text { Relawan mendukung ucapan } \\
\text { Jokowi }\end{array}$ \\
\hline 5. & $\begin{array}{l}\text { Relawan Nilai Pidato Jokowi Justru Sejuk dan } \\
\text { Membesarkan Hati }(07 / 08 / 2018)\end{array}$ & $\begin{array}{l}\text { Relawan mendukung ucapan } \\
\text { Jokowi }\end{array}$ \\
\hline 6. & $\begin{array}{l}\text { JK: Pernyataan Pak Jokowi Dalam Konteks } \\
\text { Membela Diri }(06 / 08 / 2018)\end{array}$ & $\begin{array}{l}\text { Jusuf Kalla membela ucapan } \\
\text { Jokowi }\end{array}$ \\
\hline
\end{tabular}


Tabel 2. Hasil Temuan Pada Tribunnews.com

\begin{tabular}{|c|c|c|}
\hline No & Judul Berita & \\
\hline 1. & $\begin{array}{l}\text { Soal Pidato Jokowi, Roy Suryo: Presiden Harus } \\
\text { Bijak Memilih Diksi (05/08/2018) }\end{array}$ & $\begin{array}{l}\text { Roy Suryo netral terh } \\
\text { ucapan Jokowi }\end{array}$ \\
\hline 2. & $\begin{array}{l}\text { Soal Pidato 'Berantem', Fahri Hamzah: Jokowi } \\
\text { Tidak Pernah Berpidato yang Menyatukan Rakyat } \\
(06 / 08 / 2018)\end{array}$ & $\begin{array}{l}\text { Fahri Hamzah menyalahkan } \\
\text { pidato Jokowi }\end{array}$ \\
\hline 3. & $\begin{array}{l}\text { Pidato Jokowi Soal 'Berantem" Pesannya Jelas, Pro } \\
\text { Perdamaian }(06 / 08 / 2018)\end{array}$ & $\begin{array}{l}\text { PDIP membela } \\
\text { Jokowi }\end{array}$ \\
\hline 4. & $\begin{array}{l}\text { Bamusi: Enggak Mungkin Pak Jokowi Sulut } \\
\text { Perpecahan }(06 / 08 / 2018)\end{array}$ & $\begin{array}{l}\text { Gus Falah membela ucapan } \\
\text { Jokowi }\end{array}$ \\
\hline 5. & $\begin{array}{l}\text { Pernyataan Soal Relawan Siap Berkelahi, PDIP: Pak } \\
\text { Jokowi Menegaskan Jangan Adu Fisik (05/08/2018) }\end{array}$ & $\begin{array}{l}\text { PDIP membela ucapan } \\
\text { Jokowi }\end{array}$ \\
\hline 6. & $\begin{array}{l}\text { Soal Pidato 'Berantem' Jokowi, JK: Jokowi Kan } \\
\text { Tidak Katakan Hantam, Cuma Mempertahankan } \\
\text { Diri (06/08/2018) }\end{array}$ & $\begin{array}{l}\text { Jusuf Kalla membela ucapan } \\
\text { Jokowi }\end{array}$ \\
\hline
\end{tabular}

Tabel 3. Hasil Temuan Pada Okezone.com

\begin{tabular}{|c|c|c|}
\hline No & Judul Berita & Temuan \\
\hline 1. & $\begin{array}{l}\text { Pidato Jokowi Soal Berkelahi, Pakar Linguistik: } \\
\text { Bahasanya Bukan Provokasi Tapi... } \\
(06 / 08 / 2018)\end{array}$ & $\begin{array}{l}\text { Pakar linguistik membela } \\
\text { ucapan Jokowi }\end{array}$ \\
\hline 2. & $\begin{array}{l}\text { Pidato Jokowi Soal "Berkelahi", Ngabalin: Apa } \\
\text { yang Salah Coba? } \\
(07 / 08 / 2018)\end{array}$ & Ali Moch \\
\hline 3. & $\begin{array}{l}\text { Pidato Jokowi soal Berkelahi, Fahri Hamzah: Nanti } \\
\text { Kalau Berantem Siapa yang Bertanggung Jawab } \\
(06 / 08 / 2018)\end{array}$ & $\begin{array}{r}\text { Fahri Hamzi } \\
\text { pidat }\end{array}$ \\
\hline 4. & $\begin{array}{l}\text { Tidak Mungkin Jokowi Menyulut Perpecahan } \\
(06 / 08 / 2018)\end{array}$ & $\begin{array}{r}\text { Gus Falah me } \\
\text { Jol }\end{array}$ \\
\hline 5. & $\begin{array}{l}\text { Johan Budi Sebut Kalimat "Siap Berantem" dari } \\
\text { Jokowi hanya Kiasan } \\
(05 / 08 / 2018)\end{array}$ & $\begin{array}{r}\text { Johan Budi me } \\
\text { Jok }\end{array}$ \\
\hline 6. & $\begin{array}{l}\text { Jokowi Bilang Siap Berantem, JK: Masa Diserang } \\
\text { Tak Mempertahankan Diri } \\
(06 / 08 / 2018)\end{array}$ & $\begin{array}{r}\text { Jusuf Kalla m } \\
\text { Jol }\end{array}$ \\
\hline
\end{tabular}

Dilihat berdasarkan hasil analisis menggunakan framing Robert N. Entman, Mediaindonesia.com dalam menampilkan beritanya terlihat sangat menonjolkan pembelaan terhadap ucapan yang terdapat kata "berantem". Hal ini terlihat jelas dari bagian pendefinisian masalah (define problems) dari enam berita yang ditampilkan seluruhnya menyatakan pembelaannya akan pidato tersebut. Lalu pada bagian yang memperkirakan penyebab masalah (diagnose causes) Mediaindonesia.com lebih menonjolkan bahwa penyebab dari permasalahan ini berasal dari pihak opisisi ataupun kubu lawan. Pada pemilihan narasumber pemberitaannya, seluruhnya merupakan pihak-pihak yang berasal koalisi Pemerintahan Jokowi maupun pendukung Jokowi. Maka secara otomatis isi dari pemberitaan tersebut tentunya akan membela dan mendukung pidato tersebut. Isi berita yang terlihat sangat mendukung pidato Jokowi ini dikarenakan faktor kepemilikan dari Mediaindonesia.com sendiri yang merupakan Ketua dari Partai Nasdem yang juga merupakan pihak koalisi dari pemerintahan. 
Berbeda dengan Tribunnews.com yang tidak hanya menonjolkan berita yang menunjukan pembelaan akan pidato tersebut. Tribunnews.com juga menampilkan berita yang isinya menyalahkan dan netral akan pidato tersebut. Namun jika dilihat berdasarkan pendefinisian masalah (define problems) yang ada dalam berita yang ditampilkan oleh Tribunnews.com terlihat lebih menonjolkan pembelaan akan pidato Jokowi namun tidak secara frontal seperti Mediaindonesia.com, Tribunnews.com masih menampilkan isu yang tidak tampilkan oleh Mediaindonesia.com. Hasil temuan ini juga sesuai dengan hasil wawancara yang penulis lakukan dengan Bapak Imam Wahyudi (Anggota Dewan Pes), beliau mengatakan bahwa Tribunnews.com tidak netral sepenuhnya, namun lebih cenderung mendukung Jokowi. Pemilihan narasumber juga terlihat seluruhnya merupakan pihak-pihak yang tergabung dalam partai politik, sehingga yang disampaikannya akan tergantung dari pihak mana ia berasal. Berdasarkan hasil analisis menggunakan empat perangkat framing Robert $\mathrm{N}$ Entman, berita yang ditampilkan oleh Tribunnews.com cukup banyak yang tidak memenuhi perangkat framing Robert N. Entman. Tribunnews.com lebih mengutamakan kecepatan dalam setiap pemberitaannya sehingga tidak memperhatikan pada bagian dari kelengkapan berita tersebut. Berdasarkan hasil wawancara dengan Bapak Imam, beliau mengatakan meskipun dalam pemberitaan ini membahas seputar politik, namun bisa saja sesungguhnya ini hanya untuk kepentingan bisnis dari media tersebut seperti mencari rating.

Kemudian yang terakhir ialah Okezone.com, jika dilihat berdasarkan hasil analisis yang telah dilakukan cenderung mendukung bahwa ucapan Jokowi tersebut tidaklah salah. Hal tersebut dapat dilihat dari pendefinisian masalah (define problems) yang secara keseluruhan (5 dari 6) membela pidato Jokowi. Kemudian 4 dari 6 narasumber merupakan pihak yang mendukung dari pemerintahan saat ini, kemudian sisanya merupakan pakar linguistik dan pihak yang bersebrangan dengan pemerintahan. Dengan lebih banyaknya pihak narasumber yang berasal dari kubu pemerintahan maka secara otomatis akan menyatakan bahwa ucapan tersebut tidaklah salah. Namun pemilihan narasumber yang kontra atas ucapan tersebut ialah Wakil Ketua DPR Fahri Hamzah yang juga terkenal dengan ucapan-ucapannya yang kontroversial. Pemilihan ia sebagai narasumber bisa saja semata-mata bukan untuk menimbulkan kesan netral pada media Okezone.com, namun lebih mengarah kepada rating dan kepentingan bisnis dari media tersebut.

"Bisa jadi orang memilih narasumber tarolah seperti $X$ dia ini oposan, dijadikan narasumber. Belum tentu karena ini secara editorial, secara politik memang setuju, bukan. Tapi karena kalau dia ngomong itu hitnya pasti tinggi, kenapa? Karena kalau dia ngomong itu kebanyakan asal bunyi, sehingga orang itu bisa seperti itu. Karena orang kita suka melihat orang yang asal ngomong, macem-macem, yang kontroversi”. Ujar Imam Wahyudi (Anggota Dewan Pers).

Isi berita yang cenderung mendukung Jokowi ini dikarenakan dari faktor kepemilikan media tersebut yang merupakan Ketua Umum dari Partai Perindo dan berada dalam koalisi Pemerintahan Jokowi. Hal tersebut juga dikuatkan dengan pernyataan Bapak Imam Wahyudi yang menjelaskan jika pemilik dari media berpartai/mencalonkan sebagai presiden maka paling tidak porsi pemberitaannya akan jauh lebih banyak. 


\section{Simpulan}

Mediaindonesia.com membingkai ucapan "kalau diajak berantem juga berani" tidaklah salah dan mendukung dari ucapan Jokowi dalam pidato itu. Mediaindonesia juga membingkai bahwa penyebab dari permasalahan ini berasal pihak oposisi yang tidak mendukung pemerintahan Jokowi.

Tribunnews.com dalam membingkainya lebih menonjolkan pada bagian yang mendukung dari ucapan Jokowi, namun Tribun tidak menghilangkan isu lainnya yang tidak mendukung ucapan tersebut meskipun dalam porsi yang lebih sedikit.

Okezone.com membingkai bahwa pidato tersebut tidaklah salah dan mendukung dari ucapan dalam pidato Jokowi itu, Okezone juga menonjolkan bahwa penyebab dari permasalah ini diakibatkan oleh pihak lain yang beranggapan bahwa itu merupakan bentuk provokatif.

Kemudian dari keseluruhan pemberitaan yang dilakukan oleh ketiga media tersebut tidak ditemukan perbedaan yang signifikan di antara masing-masing media, dikarenakan ketiga media ini nyatanya cenderung mendukung ke arah pemerintahan Jokowi. Perbedaan terlihat hanya dalam pemilihan narasumbernya. Mediaindonesia dan Okezone dalam pemilihan narasumbernya berasal dari pihak-pihak yang berada dalam koalisi pemerintah, sedangkan Tribunnews masih beragam dari pihak oposisi dan koalisi pemerintah.

Kemudian pemilik media yang terlibat dalam partai politik akan memberikan dampak pada isi beritanya. Mediaindonesia dan Okezone memberitakan pidato tersebut cenderung sangat mendukung karena berada dalam koalisi pemerintah, berbeda dengan Tribunnews yang tidak secara langsung mendukung dari pidato itu namun lebih mengarah pada kepentingan bisnis.

\section{Ucapan Terima Kasih}

Ucapan terima kasih penulis berikan kepada narasumber yang telah bersedia untuk meluangkan waktunya dan memberikan informasi kepada peneliti. Peneliti juga ingin mengucapkan terima kasih kepada semua pihak Fakultas Ilmu Komunikasi Universitas Tarumanagara yang telah membantu dan memberikan kesempatan kepada penulis untuk melaksanakan penelitian ini.

\section{Daftar Pustaka}

Entman, Robert. (1993). Framing: Toward Clarification Of A Fractured Paradigm. Journal Of Communication. 43(4). 51-58.

Eriyanto. (2011). Analisis Framing: Konstruksi, Ideologi, dan Politik Media. Yogyakarta : LkiS.

Miles, B. Mathew, \& Michael Huberman. (1992). Analisis Data Kualitatif Buku Sumber Tentang Metode-metode Baru. Jakarta: Universitas Indonesia.

Romli M, Asep (2012). Jurnalistik Online. Bandung: Nuansa Cendikia. 